\title{
CORRESPONDENCE
}

\author{
To the EDItor of Philosophy
}

\section{ARTHUR STANLEY EDDINGTON MEMORIAL LECTURESHIP}

DeAr Sir,

Arthur Stanley Eddington was one of the few recent scientific thinkers of the first rank who have attempted to think out a view of the world which would do justice to all fields of knowledge and experience. Of world-wide fame as an astronomer and mathematician, he combined great powers of scientific and philosophical analysis with a deep religious faith and a practical mysticism which found expression in his active and life-long membership of the Society of Friends, and in his intense concern for the ways of peace. These qualities together with his humility and simplicity, made it possible for him to understand the needs and perplexities of ordinary thinking men. And the simple and vivid style in which he lectured and wrote enabled him to communicate to non-specialists an appreciation of the essence of scientific thought as well as of some of the most recondite advances in physics and astronomy. What makes Eddington such an important figure in contemporary thought is not that the synoptic view of the world which he put forward is necessarily the one which will vltimately be found to be nearest the truth, but that he saw that a synoptic view was necessary, and that we cannot be content with a departmentalization of knowledge in which science appears to be disconnected from the other fields of human enquiry-philosophical and religious.

We desire that there should be for Eddington a fitting memorial-one that would maintain and further his own concern for relating the scientific, the philosophical and the religious methods of seeking truth, and which would help to develop that insight into the unity underlying these different methods which was the characteristic aim of his work. We believe that the foundation of an Arthur Stanley Eddington Memorial Lectureship, providing for periodical lectures on some aspect of contemporary scientific thought considered in its bearings on the philosophy of religion or on ethics, to be delivered in Cambridge or elsewhere and to be published, would be well calculated to achieve this object.

To establish this memorial lectureship will require a capital sum of about $£ 2,500$. An Appeal Committee has been formed in Cambridge to receive subscriptions, which may be sent to Barclays Bank Limited, Cambridge, for the credit of "The Arthur Stanley Eddington Memorial Lectureship" account, or to the Honorary Secretary, Dr. W. H. Thorpe, Jesus College, Cambridge, or to the Honorary Treasurer, Howard Diamond, A.C.A., 45, St. Barnabas Road, Cambridge. The Honorary Secretary will be pleased to send to those interested details of the plan proposed for administration of the Lectureship for which the Royal Society, Trinity College, Cambridge, and the Society of Friends have agreed to appoint Trustees.

We warmly commend this appeal.

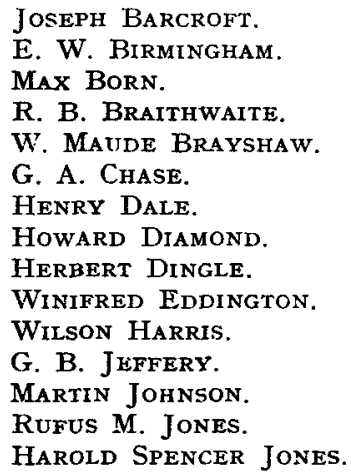

Kathleen Lonsdalf.

E. J. Maskell.

A. Victor Murray.

C. E. Raven.

F. J. M. Stratton.

Hilda Sturge.

W. H. THORPE.

HenRy T. Tizard.

G. M. Trevelyan.

Elsie Watchorn.

A. N. Whitehiad.

Edmund T. WhitTaker.

AlEx. Wood.

HI. G. WooD. 